\title{
ENTOMOLOGY
}

\section{Associations between the larval-pupal parasitoids Erycia furibunda and E. festinans (Diptera: Tachinidae) and respectively, the sympatric and syntopic butterflies Euphydryas aurinia provincialis and Melitaea cinxia (Lepidoptera: Nymphalidae)}

\author{
M. Pinzari, ${ }^{1}$ M. Pinzari, ${ }^{2}$ D. Cesaroni, ${ }^{1}$ \\ ${ }^{1}$ Department of Biology, University of Roma Tor Vergata, Rome; ${ }^{2}$ Amateur entomologist, Rome, Italy
}

\begin{abstract}
Several studies on butterfly ecology and biology of Melitaeini butterflies have been carried out in the past, however the factors affecting butterfly mortality and the role of natural enemies on population dynamics are not yet fully known. Larval survival plays a key role in determining butterfly population size and distribution range; thus, knowing the sources and variation in larval mortality is essential understanding and predicting population dynamics. Butterfly larval mortality is generally ascribed to abiotic factors, predators and parasitoids (mainly Diptera and Hymenoptera). Among Diptera, tachinids parasitize primarily larval Lepidoptera. In this paper, we report the results of 5-year observations in the wild and captivity on the tachinids, Erycia furibunda and E. festinans, parasitoids of caterpillars of a population of Euphydryas aurinia spp. provincialis and Melitaea cinxia in Central Italy
\end{abstract}

Correspondence: Manuela Pinzari, Department of Biology, University Tor Vergata of Rome, via della Ricerca Scientifica 1, 00133 Rome, Italy.

Tel.: +39.06.72595950 - Fax: +39.06.72595965.

E-mail: manuela.pinzari@uniroma2.it

Key words: parasitoids, flies, butterflies.

Contributions: the authors contributed equally.

Conflict of interest: the authors declare no potential conflict of interest.

Funding: none

Received for publication: 28 September 2019

Revision received: 5 March 2020.

Accepted for publication: 3 April 2020.

${ }^{\circ}$ Copyright: the Author(s), 2020

Licensee PAGEPress, Italy

Journal of Entomological and Acarological Research 2020; 52:8582

doi:10.4081/jear.2020.8582

This article is distributed under the terms of the Creative Commons Attribution Noncommercial License (by-nc 4.0) which permits any noncommercial use, distribution, and reproduction in any medium, provided the original author(s) and source are credited. revealing their host specifity. The hosts, E. aurinia and $M$. cinxia, and parasitoids, E. furibunda and E. festinans, inhabit the same habitat and their life cycles highly overlap, nevertheless, the parasitoids maintain their host specifity: E. furibunda as parasitoid of E. aurinia; E. festinans as parasitoid of M. cinxia. This was confirmed by our findings during the butterfly breeding activities carried out for over five years. Although the role of chemical cues in host finding requires further research, according to our observations the presence of only E. furibunda on larval webs of E. aurinia let us suppose that the mechanism by which $E$. furibunda locates its host could be based on olfactory cues emitted by feeding damage to host plants that act from afar. Similarly, the mechanism of host finding used by $E$. festinans could act to select its host, $M$. cinxia. Furthermore, we illustrate some diagnostic features of adults for the identification of the studied parasitoids.

\section{Introduction}

Parasitoids of butterflies fall into two insect orders, Diptera and Hymenoptera. They are of vast importance in all ecosystems as they control the population size of many of their hosts.

Several families of Diptera behave as parasitoids but only one, the large family Tachinidae, includes regular and important parasitoids of butterflies (Mellini, 1991; Belshaw, 1994; Cerretti \& Tschornig, 2010). Despite their diversity and ecological impact, relatively little is known about the biology and basic ecology of tachinids and most species are still unidentified (Stireman et al., 2006). Regarding the oviposition strategies, tachinids may adopt direct or indirect strategies to lay their eggs, depending on the species (Dindo, 2011). In direct strategies, oviposition may occur in diverse modalities, for example projecting or depositing eggs on the host integument (i.e. Exorista larvarum [Linnaeus 1758]) or inserting them into the host body (i.e. Compsilura concinnata [Meigen 1824] (Dindo \& Nakamura, 2018). In indirect strategies, the ovoviviparous females may lay eggs close to a host, where the newly-hatched parasitoid larvae (of the planidium type) wait for a host to pass by. Moreover, some tachinids lay tiny microtype eggs on the host food (generally plant leaves) and these eggs hatch only after been ingested by a host. This strategy allows to parasitoids to reach hosts that live in concealed places (i.e. caterpillars inside their silken nest) that are inaccessible to females (Dindo \& Grenier, 2014). The mechanisms of host selection in dipterans are related to 
their oviposition strategy. In dipteran parasitoids with direct strategies, females may use chemical cues to locate the host or the habitat of the host perceiving the stimuli derived from the interaction between the host and the plant it feeds on. Visual cues (i.e. host colors and movements) may also play a key role in host location in tachinids (Godfray, 1994; Dindo \& Grenier, 2014; Depalo et al., 2012). In fly species with indirect oviposition or larviposition strategy, females use physical and chemical cues for locating only the host habitat or microhabitat (Mellini et al., 1980). Furthermore, associative learning through experience to locate a host has been documented in some tachinids species. Though superparasitism in the parasitic Diptera appears to be both widely distributed across species and common within populations, also the capacity to avoid superparasitism by recognizing previously parasitized hosts has been observed, but in a few cases (Feener \& Brown, 1997; Dindo \& Grenier, 2014). In the case of Tachinidae visual stimuli also play a role in host-searching behaviour by parasitoids (Stireman et al., 2006). However, the mechanisms of host selection in Tachinidae, including the role of the host-plant, remain partially unknown, as few studies have been performed on these topics.

Tachinids parasitize an extensive range of plant-feeding insects and their hosts are primarily larval Lepidoptera belonging to many families. Many species are polyphagous and generalist, whereas others are extreme specialists exhibiting relatively narrow host ranges.

Among the butterflies belonging to the family Nymphalidae, the data concerning the dipteran parasitoids are really poor to the best of the authors' knowledge, especially for species in the Melitaeini tribe. Some host associations of tachinid taxa with Melitaeini species have been summarised in Van Nouhuys \& Hanski (2004) and Shaw et al. (2009), but little is still known about the species of dipteran parasitoids and their biology.

The marsh fritillary butterfly, Euphydryas aurinia (Rottemburg 1775) (Nymphalidae, Melitaeini) is a butterfly species protected under the Habitats Directive (Annex II) and its subspecies provincialis (Boisduval 1828) was classified as "Least concern" in the IUCN Red List for Italian butterflies (Balletto et al., 2015).

In this framework, in the context of an ongoing survey of the Lepidoptera fauna in Italy (Pinzari et al., 2010, 2018a, 2018b, 2019a; Pinzari \& Sbordoni, 2013; Pinzari, 2016a; Pinzari \& Pinzari, 2019a, 2019b, 2019c), we extensively investigated many aspects of biology of a population of $E$. aurinia provincialis living in Central Italy: larval host plants preference, predators, adult population dynamics, mating behaviour and parasitoids (Pinzari, 2016b, 2019; Pinzari et al., 2016, 2017, 2019a, 2019b).

E. a. provincialis is a monovoltine butterfly, which is limited to the Maritime Alps and the Apennine Mountains (Balletto et al., 2014). It is characterized by six larval stages. The I-IV instar caterpillars are gregarious, then the V-VI-instar larvae are solitary (Pinzari et al., 2016). Given the high number of individuals in a larval web, gregarious caterpillars represent an important food source for arthropods and small mammals (Van Nauhuys \& Hanski, 2004; Pinzari, 2016b, 2019; Pinzari et al., 2019a). The amount of larval survival plays a key role in establishing butterfly population size and distribution range; thus, knowing the sources and variation in larval mortality is essential to understand and predict population dynamics (Van Nauhuys \& Hanski, 2004). In Europe, the known parasitoids of E. aurinia aurinia belong to Tachinidae and larval parasitoids are: Chetogena rondaniana (Villeneuve 1931), Compsilura concinnata (Meigen 1824), Erycia furibunda (Zetterstedt 1844) (Shaw et al., 2009; Stefanescu et al., 2009) and E. fatua (Megan 1824) (Porter, 1981; Van Nouhuys \& Hanski, 2004). Our studies confirmed the host association between E. aurinia and Erycia furibunda and revealed some aspects of the parasitoid life cycle in Central Apennines (Latium,
Central Italy) (Pinzari et al., 2017). Here, we also detected the cooccurrence of two species belonging to the genus Erycia: E. furibunda and E. festinans. Herting (1960) described E. festinans as an ovolarviparous parasitoid of the first instar larvae of Euphydryas (Meigen 1824) aurinia, but recently Tschorsnig (2018) said that this information was likely to be wrong due to erroneous species determination. According to Herting (1960), E. festinans is also a larval pupal parasitoid of the Glanville fritillary, Melitaea cinxia (Linné 1758), that occurs together with E. aurinia in our study area (Pinzari et al., 2010). Melitaea cinxia is a montane butterfly and is present throughout continental Italy and in Sicily (Balletto et al., 2014).

The presence of populations of E. a. provincialis and M. cinxia from the area of Vallemare (Rieti, Lazio, Central Italy, Location WGS84: N42.4836 ${ }^{\circ}-\mathrm{E} 13.1148^{\circ}$ ) was reported by Pinzari et al. (2010). In this area, E. a. provincialis and M. cinxia inhabit the same habitat patches in montane grassland and slopes at $1000 \mathrm{~m}$ and the adult flight period (from the middle of May to the early days of July) and larval stages overlap. Females of E. a. provincialis oviposit on the plants Gentiana cruciata L., Scabiosa columbaria L. and Cephalaria leucantha (L.) Roem. \& Schult., and caterpillars feed on these host plants and also Lonicera caprifolium L. (Pinzari et al., 2016). Females of M. cinxia lay their eggs on the plants of Plantago lanceolata L. and Veronica spicata L. (Kuussaari et al., 1998, Kuussaari et al., 2004). In both species, the I-III instar larvae are gregarious and spin a communal "feeding" web on the host plants. They typically remain in groups until the beginning of the last molt larval instar in M. cinxia (Kuussaari et al., 2004) and until the IV larval instar in E. a. provincialis (Pinzari et al., 2016). Then, they become solitary and pupate within the vegetation close to the ground.

The aim of this paper is to shed some light on the host-parasitoid association between the two Diptera species, Erycia furibunda and E. festinans, and the two Melitaeini butterfly species, E. $a$. provincialis and $M$. cinxia. For this purpose, we carried out observations in the field on larval stages of the two butterfly species in the areas where the butterflies were found to coexist with both of the parasitoids. After that, we reared the caterpillars in a laboratory until the Erycia fly emerged from butterfly pupae in order to detect the host specificity of parasitoids.

\section{Materials and Methods}

\section{Sampling of $M$. cinxia and of $E$. a. provincialis larvae}

From 2015 to 2019, in April we collected larvae of M. cinxia and E. a. provincialis at their solitary stage (V-VI instar) across a wide area (ca. 2 ha) near the "crossroads Santa Maria del Monte", $1000 \mathrm{~m}$ (Pinzari et al., 2010) at few kilometers from the locality Vallemare (Rieti, Italy). In 2019, we additionally collected larvae at IV-V instar to investigate other egg or larval parasitoids.

M. cinxia and E. a. provincialis are easily distinguishable at larval stage after the III instar on the basis of the colour of the cephalic capsule: red in M. cinxia, black in E. a. provincialis.

\section{Rearing of $M$. cinxia and $E$. a. provincialis larvae}

The larvae were reared individually inside small glass jars (diameter $=4 \mathrm{~cm}$, height $=5 \mathrm{~cm}$ ) with netted plugs in a laboratory in Rome at room conditions (ca. $20-22^{\circ} \mathrm{C}$; $45-60 \%$ relative humidity; natural photoperiod, 12-hour light-dark cycle) until pupation. The larvae of $M$. cinxia were fed mainly with leaves of Plantago sp. and E. a. provincialis with shoots of Lonicera caprifolium L. Every day, in the morning and in the evening, we provided fresh leaves to the larvae and cleaned the glass jars removing the faeces to avoid the formation of mold. 
The species identification of parasitoids was performed after emergence by the methods described in the following paragraph.

\section{Monitoring and sampling of Erycia adult parasitoids}

In the context of previous field-work on all stages of the life cycle of E. a. provincialis (Pinzari et al., 2016) we discovered the presence and identified the period during which $E$. furibunda females locate their hosts and parasitize the larvae of $E$. $a$. provincialis. The monitoring of butterfly life cycle was carried out over five years every week in Spring and Summer and every 15 days during the rest of the year. This monitoring focused on egg batches and larval webs as following: eggs (from May to the end of June); pre-diapause gregarious phase (I-III instar on larval webs) (from May to September); diapause phase (IV instar in larval webs) (from September to mid-February); post-diapause gregarious phase (IV instar) (from mid- February to mid-March); and solitary caterpillars (V-VI instar) (from March to mid-April) (Pinzari et al., 2016). The appearance of adult parasitoids on the butterfly larval webs was conditioned by the hatching of $E$. a. provincialis eggs and also the development time of the caterpillars. A detailed article on this topic is in preparation (Pinzari, unpublished data). Therefore, in Summer, in order to ascertain when and how long female parasitoids inhabit the butterfly larval webs for oviposition, from the second week of June up to the second week of September, we intensified the controls and every day we visited the butterfly host plants with and without larval webs in the study area and recorded presence/absence of Erycia flies. During five years of observations, 24th June was the earliest record and 29th August was the latest date of the occurrence of Erycia furibunda on the larval webs of E. a. provincialis.

The flies were photographed in the field and/ or collected on sight. They were collected in the daytime, when they rested on butterflies host plants or in the surrounding plants during feeding, by butterfly net.

\section{Species identification of parasitoids}

Adults of E. furibunda and E. festinans were identified by their habitus (Tschorsnig \& Herting, 1994) and in particular on the basis of the colour of the basicosta (the distal plate in the axillary area of the wing). This is black and yellow in E. festinans (Figure 1A), completely yellow in E. furibunda (Figure 1B) and entirely black

\section{Erycia festinans}
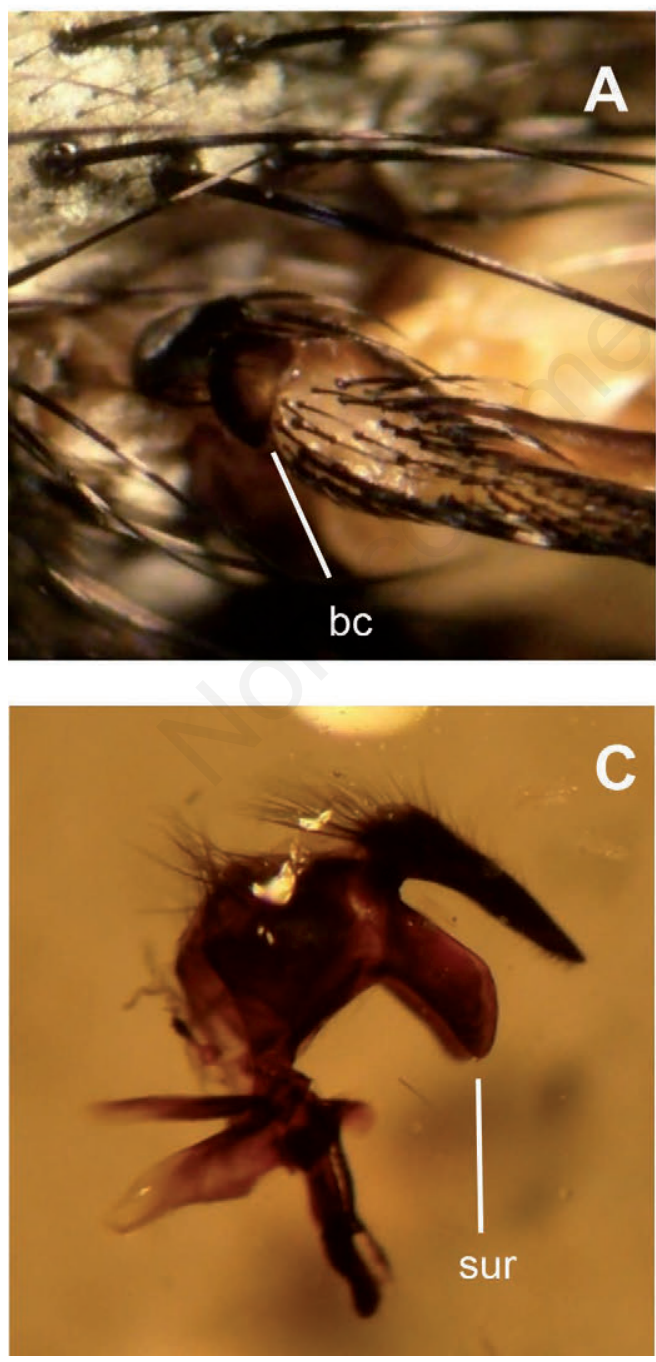

\section{Erycia furibunda}
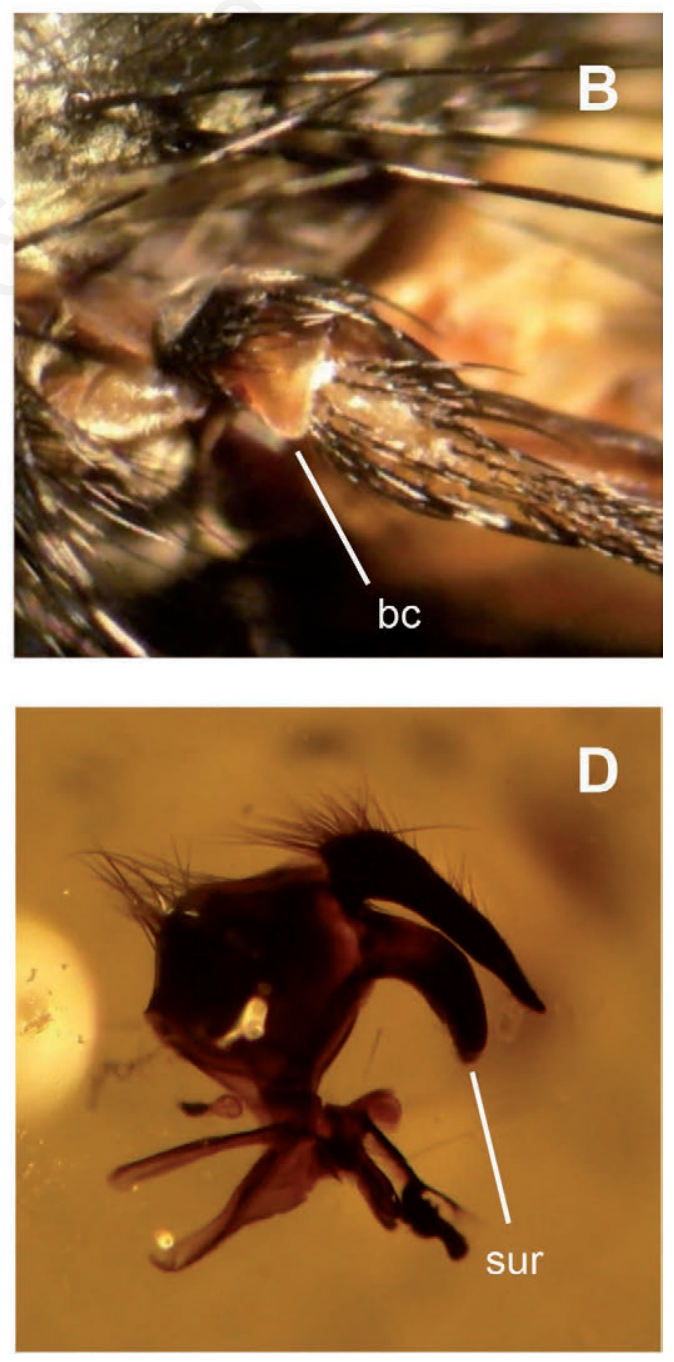

Figure 1. Diagnostic features for tachinid identification: A and B, basicosta in the axillary area of the wing along which the costa of the wing articulates; $\mathrm{C}$ and $\mathrm{D}$, male hypopygium in lateral view. Abbreviations: bc = basicosta; sur = surstylus. 
in E. fatua. Erycia fatua is morphologically very similar to $E$. festinans (Herting, 1960; Tschorsnig \& Herting, 1994). Having the same hosts, there remains some doubt if they are really separate species (Tschorsnig, 2018). Specimens of E. furibunda and $E$. festinans were sexed after death. The species determination of males was confirmed by the examination of genitalia (Figures 1C and 1D).

P. Cerretti (Rome, Italy), H. Tschorsnig (Germany) and M.R. Shaw (Edinburgh, United Kingdom) confirmed identification of parasitoids and helped in sexing of individuals. These specimens are presently preserved in the Mario Pinzari's Collection in Rome (Italy).

\section{Rearing of parasitoids}

A parasitized pupa was identified by its change in colour from the typical whitish colour to reddish and later to dark brown; on the contrary, when the pupa is parasitoid-free it maintains its typical whitish colour and becomes transparent when the adults of $E$. $a$. provincialis emerge. The pupae were isolated and labelled. In the case of parasitized pupae, when the maggots were left to pupate and the puparia were individually kept in separate small glass jars (with one open netted side) at room conditions (ca. $20-22^{\circ} \mathrm{C} ; 45-60 \%$ relative humidity; natural photoperiod, 12 -hour light-dark cycle) until the fly emergence. The pupae with no evidence of parasitization were also isolated and monitored until butterfly emergence or decease.

We additionally identified the species of the dead puparia by studying the content of puparia. The dead puparia were boiled in $10 \%$ potassium hydroxide solution for few minutes. The species determination was possible only when the flies completed the metamorphosis. The species determination of one of these specimens diverse from Erycia was committed to Dr Hans-Peter Tschorsnig (Staatliches Museum für Naturkunde Stuttgart, Germany).

Parasitized larvae by Hymenoptera were reared according to the rearing methods described above. Braconids and Ichneumonids emerged from butterfly larvae were preserved in dry condition or in alcohol 90\%. They were identified by Dr. Mark R. Shaw (National Museums Scotland, Edinburgh, United Kingdom).
Both larvae and pupae were monitored at two fixed times, 7 AM and $7 \mathrm{PM}$, and also randomly at night and day.

The adults and all material from the rearing (parasitized butterfly pupae, puparia, etc.) are presently preserved in the Mario Pinzari's Collection in Rome (Italy).

\section{Rate of dipteran parasitism}

From pupae diverse species of Diptera, beside Erycia species emerged. Accordingly, for each butterfly species, we calculated: 1) the rate of dipteran parasitism (RPD), as the ratio between the number of emerging maggots (without distinguishing parasitoid dipteran species) from butterfly pupae and the total number of pupae; 2) the rate of Erycia parasitism (RPE), as the ratio between the number of emerging maggots of Erycia parasitoids from butterfly pupae and the total number of pupae (Table 1).

Rates of parasitism among years were compared and tested for significance using the Chi-Square test. All data analyses were performed in STATISTICA version 7.

\section{Results}

\section{Sampling of $E$. a. provincialis and $M$. cinxia}

We collected a total of 317 larvae of E. a. provincialis (in 2015, 28 individuals; in 2016, 50, Pinzari et al., 2017; in 2017, 25; in 2018,46 and in 2019,168 ) and a total of 75 larvae of $M$. cinxia (in 2017, 28 larvae; in 2018, 22, and in 2019, 25).

\section{Observations and records of $E$. furibunda and E. festinans adults in the wild}

From 2015 to 2019, during July-August, we monitored $G$. cruciata, $S$. columbaria and Plantago sp. plants with and without larval webs in the study area to record Erycia parasitoids during the oviposition period. We collected twenty-three females of $E$.

Table 1. Rearing results and Ratio of Parasitism of E. a. provincialis - E. furibunda and M. cinxia - E. festinans systems.

\begin{tabular}{|c|c|c|c|c|c|c|c|c|c|c|}
\hline \multicolumn{2}{|c|}{ Caterpillars } & \multicolumn{4}{|c|}{ Pupae } & \multicolumn{3}{|c|}{ Puparia } & \multicolumn{2}{|c|}{ Adult sex } \\
\hline & Total & Total & Adult & Dead & $\begin{array}{l}\text { Parasitized } \\
\text { (RPD) }\end{array}$ & Adult & Dead & $\begin{array}{l}\text { Parasitized } \\
\text { (RPE)* }\end{array}$ & Males* & Females* \\
\hline & & \multicolumn{4}{|c|}{ Euphydryas aurinia provincialis } & \multicolumn{5}{|c|}{ Erycia furibunda } \\
\hline $\mathrm{N}$ & 25 & 25 & 13 & 8 & $4^{(2)}$ & 3 & 0 & 3 & 2 & 1 \\
\hline$\%$ & - & 100 & 52 & 32 & 16 & 100 & 0 & 12 & 67 & 33 \\
\hline $\mathrm{N}$ & 46 & 44 & 32 & 3 & $9(4)$ & 5 & $3^{(7)}$ & 8 & 5 & 3 \\
\hline$\%$ & - & 96 & 73 & 7 & 20 & 63 & 37 & 18 & 62 & 38 \\
\hline $\mathrm{N}$ & $168^{(5)}$ & 121 & 59 & 38 & $24^{(6)}$ & 18 & $2^{(7)}$ & 20 & 6 & 14 \\
\hline \multirow[t]{2}{*}{$\%$} & - & 72 & 49 & 53 & 20 & 90 & 10 & 16 & 30 & 70 \\
\hline & & \multicolumn{4}{|c|}{ Melitaea cinxia } & \multicolumn{5}{|c|}{ Erycia festinans } \\
\hline $\mathrm{N}$ & 28 & 27 & 13 & 7 & 7 & 6 & $1^{(1)}$ & 7 & 3 & 4 \\
\hline$\%$ & - & 96 & 48 & 26 & 26 & 86 & 14 & 26 & 43 & 57 \\
\hline $\mathrm{N}$ & $22^{(3)}$ & 19 & 16 & 1 & 2 & 2 & 0 & 2 & 0 & 2 \\
\hline$\%$ & - & 86 & 84 & 5 & 10 & 100 & 0 & 10 & 0 & 100 \\
\hline $\mathrm{N}$ & 25 & 18 & 10 & 0 & 8 & 8 & 0 & 8 & 5 & 3 \\
\hline$\%$ & - & 72 & 40 & 0 & 44 & 100 & 0 & 44 & 62 & 38 \\
\hline
\end{tabular}

RPD, rate of dipteran parasitism of the pupae, as the ratio between the number of emerging maggots (without distinguishing parasitoid dipteran species) from butterfly pupae and the total number of pupae; RPE, rate of Erycia parasitism of the pupae, as the ratio between the number of emerging maggots of Erycia parasitoids from butterfly pupae and the total number of pupae; as concerns puparia, the \% of the dead and adults have been calculated on the total of parasitized pupae, while the $\%$ of fly sexes on the total of producing adults (including the sexed dead puparia).

${ }^{(*}$ it also included the dead puparia whose species was identified at this stage. ${ }^{(1)}$ it was identified as a female at puparium stage and then included in adult sex column. ${ }^{(2)}$ one puparium of these pupae died and was identified as tachinid by Tschorsnig. ${ }^{(3)}$ out of 22 caterpillars, 2 died due to the parasitism by Hyposoter horticola (Hymenoptera). ${ }^{(4)}$ out of 9 chysalides, 1 was parasitized by a dipteran parasitoid which was unidentified due to absence. ${ }^{(5)}$ out of 168 caterpillars, 8 died due to the parasitism by Cotesia sp. and Gelis sp. (Hymenoptera). ${ }^{(6)}$ out of 24 puparia, 20 gave rise to Erycia furibunda adults, 4 died and did not complete the metamorphosis; these were identified as diptera. ${ }^{(7)} 2$ puparia were sexed after boiling of the puparia and then included in "Adult sex" column. 
furibunda (Pinzari et al., 2017) and only two females of E. festinans. These rested on grass and were far from the larval webs of both butterflies. We never recorded Erycia species on the larval webs of $M$. cinxia or E. festinans on the larval webs of E. a. provincialis.

E. festinans. Collected specimens: Borbona (RI), Italia, Fraz. Vallemare, 1 ㅇ, S. Maria Incrocio, 1000 m, 15.VII.2017, 1 q, idem, 5.VIII.2017, Manuela \& Mario Pinzari leg.

E. furibunda. Collected specimens: Borbona (RI), Italia, Fraz. Vallemare, 2 우, S. Maria Incrocio, $1000 \mathrm{~m}, 2$.VIII.2015, 2 우우, idem 5.VIII.2015, 1 q, idem, 7.VIII.2015, 4q , idem, 24.VII.2016, 1 q, idem, 30.VII.2016, 1 q, idem, 1.VIII.2016, 1 q, idem, 4.VIII.2016, 2 우, idem, 10.VIII.2016, 1 ㅇ, idem, 12.VIII.2016, 1 , idem, 19.VIII.2016, 1 o, idem, 24.VIII.2016, 1 , idem, 29.VIII.2016, 2 q o , idem, 24.VI.2017, 1 q, idem, 8.VII.2017, 1 q, idem, 8.VIII.2017; 1 q, Bivio Brignola, 1062 m, 30.VII.2017; Manuela \& Mario Pinzari leg. (Pinzari et al., 2017).

\section{Rate of parasitism}

A first remarkable result was that the Erycia emerging from $E$. a. provincialis larvae was only E. furibunda and from M. cinxia was only E. festinans in our study locality.

From 2017 to 2019 years, out of 239 reared caterpillars of $E$. $a$. provincialis, 49 larvae died during observations for unknown causes and 190 pupated. Out of 190 pupae, 55\% became butterflies, 26\% died for unknown reasons, $19 \%$ died due to the presence of parasitoids (Table 1). For M. cinxia, from 2017 to 2019, out of 75 caterpillars, 64 formed the pupae and 11 died. Out of 64 pupae, $61 \%$ became butterflies, $12 \%$ died for unknown reasons, $26 \%$ died for parasitoids (Table 1).

Concerning Erycia furibunda, in 2015-2016, 31\% of puparia died for unknown reasons, and the remaining 69\% gave rise to 9 adults with a male-biased sex ratio (2:1) (Pinzari et al., 2017). From 2017 to 2019 years, $16 \%$ of puparia died for unknown reasons, while $84 \%$ gave rise to 31 adults with a weakly female-biased sex ratio 1.4) (Table 1). In 5-years of investigation, we found a continuous incidence of the parasitoid E. furibunda on mortality of $E$. $a$. provincialis caterpillars with the following RPE values: $2015=4 \%$; $2016=24 \%, 2017=12 \%, 2018=18 \%, 2019=16 \%$ (Figure 2 ). There were not statistically significant differences among years when the rates of parasitism were compared. $\left(\chi^{2}=6.485, \mathrm{df}=4, \mathrm{p}=0.16\right)$.

As regards Erycia festinans, in 3-years of investigation (20172019) $6 \%$ of puparia died and the remaining $94 \%$ gave rise to 16 adults with a sex ratio 1:1 (Table 1). In $M$. cinxia, the parasitoid $E$. festinans affected the survival of the caterpillars with a RPE equal to $26 \%, 10 \%$ and $44 \%$ respectively in 2017,2018 and 2019 $\left(\chi^{2}=5.047, \mathrm{df}=2, \mathrm{p}=0.08\right)$ (Table 1, Figure 2).

\section{Rate of parasitism of other parasitoids of $E$. aurinia provincialis}

Our observations in 2017 and 2019 years also revealed other larval pupal parasitoids of E. a. provincialis. In 2017, one fly (as a maggot), different from Erycia festinans and Erycia furibunda, emerged from a caterpillar of E. a. provincialis. It was determined at puparium stage as belonging to the family of Tachinidae by Tschorsnig (personal communication on Apr 12, 2019) and it is yet under study. In 2019, eight E. a. provincialis caterpillars showed some parasitic species of Hymenoptera, particularly braconid and ichneumonid species (possibly, Cotesia sp. and Gelis sp., Dr. Mark R. Shaw, personal communication on Jun 18, 2019).

Taking into account only the dipteran parasitoids, for $E$. $a$. provincialis the rates of parasitism (RPD) were comparable in $2017-$ 2019 years (Table 1 ).

\section{Discussion}

Most efforts for butterfly conservation biology have been focused on getting the 'bottom-up' aspects of the habitat (host plant abundance, vegetation characteristics of host plant cover, thermal conditions of the sites, etc.) right for the dwindling butterfly population, on the contrary parasitoids and other 'top-down'

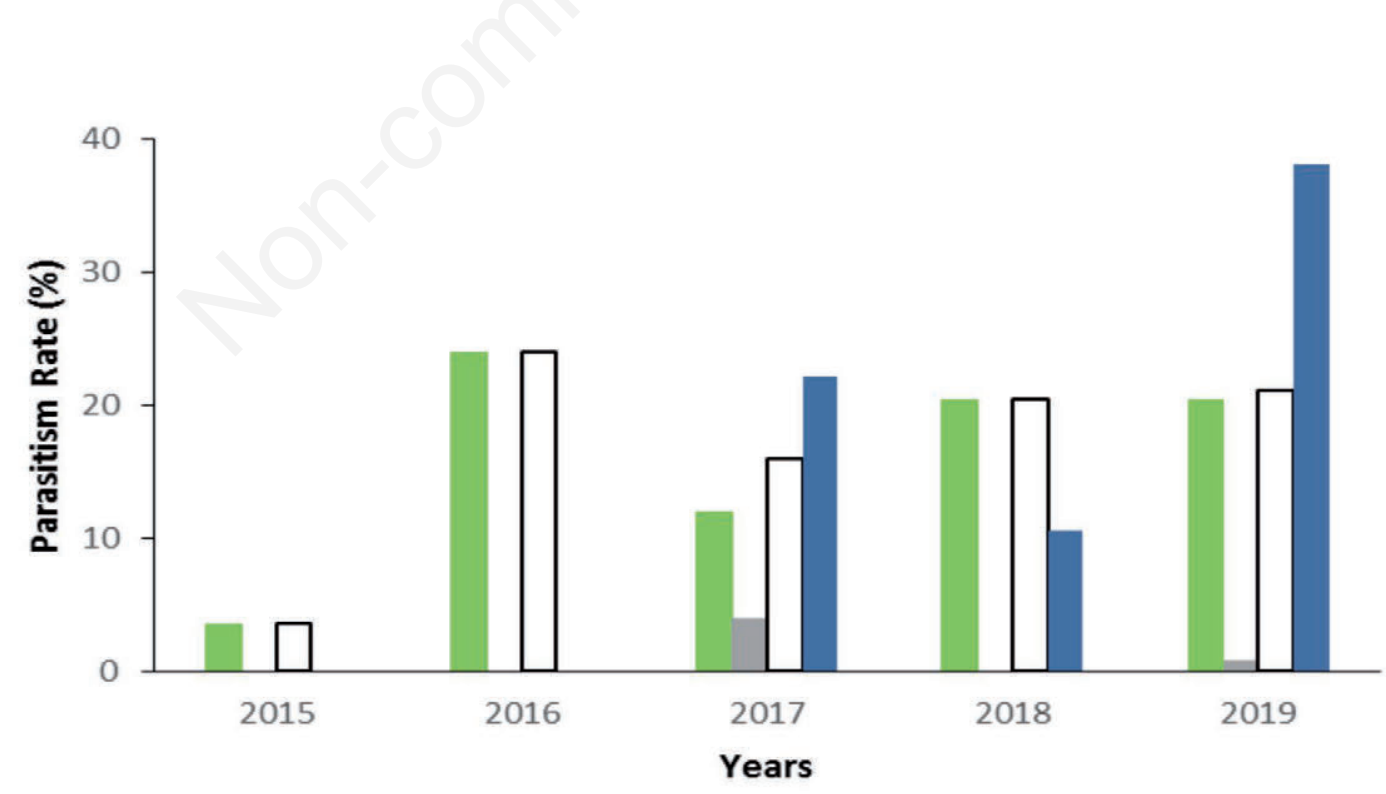

\section{E. furibunda not identified tachinids aTotal $\quad$ E. festinans}

Figure 2. Parasitism Rates of pupae of: Euphydrias aurinia (2015 - 2019) by Erycia furibunda (green), other non-identified tachinids (grey), non-identified Diptera (black) and total dipteran parasitoids (RPD)(white); Melitaea cinxia by Erycia festinans. Data collected in 2015 and 2016 years are from Pinzari et al., (2017). 
influences have generally been ignored (with some notable exceptions, see Shaw et al 2009). Many works on butterfly parasitoids are mere compilations of the host-parasitoid records found in the literature, plagued with errors, ambiguity and nonquantitative data (Ford \& Shaw, 1991; Shaw et al., 2009; Cerretti $\&$ Tschorsnig, 2010). To prevent these problems, researchers need an assessment of recorded specimens by expert taxonomists and host data for parasitoids based on reared specimens. It is also important to establish a comprehensive knowledge of which species parasitize butterfly species and if a strict host-parasitoid association exists. However, it is hard to establish if a strict host-parasitoid association exists, especially in the case of tachinids. You may establish that a certain tachinid species successfully parasitize a host species as in the case of Erycia furibunda and E. festinans, but it is hard to exclude that other species may serve as suitable hosts. In fact, many tachinids are polyphagous and generalist and, often, the hosts are still unidentified (Dindo \& Grenier, 2014).

\section{Host association}

In the study area, adults of the larval-pupal parasitoids, Erycia furibunda and E. festinans, emerged from puparia in the same area where the host butterflies, M. cinxia and E. a. provincialis, occurred.

It is known from the literature as Erycia furibunda behaved hilltopping for mating purposes: males emerged before females and moved to the nearby hill reliefs waiting for females to mate (Tschorsnig, 1996; Pinzari et al., 2017). Throughout our study, we looked for the hill-topping behaviour of the species on the nearby reliefs in the study area, but unsuccessfully. We recorded only females of Erycia furibunda and E. festinans inhabiting their birth area for oviposition. Erycia furibunda oviposits on the larval web of $E$. aurinia provincialis and nearby eating caterpillars when the host larvae were at early larval stages before winter diapause (Pinzari et al., 2017). E. furibunda and perhaps E. festinans might adopt an indirect oviposition strategy as witnessed even up to other tachinids (Dindo, 2011; Dindo \& Grenier, 2014).

During the field phase, we were able to easily observe females of E. furibunda laying eggs on E. a. provincialis pre-hibernation larval webs on $G$. cruciata and $S$. columbaria. Indeed, we made multiple observations and even up to three females of E. furibunda were simultaneously seen on the same larval webs of $E$. a. provincialis (Pinzari et al., 2017). On the contrary, it was more difficult to record females of E. festinans looking for their host M. cinxia on Plantago plants. E. festinans seems much less common than E. furibunda and we never recorded any parasitism event on $M$. cinxia.

In order to not disturb the balance between the butterfly, E. $a$. provincialis, and the studied parasitoids, we did not capture all Erycia flies observed on the butterfly larval webs on gentians or small scabious plants; thus, we cannot completely exclude that there could be individuals of both species, furibunda and festinans, on $E$. a. provincialis nests.

On the whole, in 3-years of investigation (2015-2017) we collected twenty-one females of $E$. furibunda on larval webs of $E$. a. provincialis, and no females of E. festinans or E. furibunda on the nests of M. cinxia on Plantago plants. The only two females of E. festinans were collected in the wild far from butterfly larval webs and also host plants.

In this study, the most important evidence of host association between butterfly and parasitoid species derived from the rearing observations, making it possible to associate E. festinans to $M$. cinxia and E. furibunda to E. a. provincialis, on the basis of the maggots emerging from butterfly species. In fact, only $E$. furibunda emerges from the pupae of E. aurinia, while E. festinans emerges only from pupae of $M$. cinxia. We cannot exclude that other butterflies may serve as suitable hosts for the studied Erycia species.

\section{Host finding}

The caterpillars of $M$. cinxia and E. a. provincialis have similar habitus in early stages; only after the III instar the colour of the cephalic capsule is different. Both butterflies share the larval lifestyle in a communal silken web in the same period and in the same places but they live on different host plants.

How do Erycia species locate and recognize host caterpillars? The information available indicates that tachinids use a wide diversity of cues (olfactory, visual, auditory, and tactilechemosensory) to find their hosts. Many tachinids depend on chemical cues derived from the plants of their phytophagous insect hosts. Chemical cues may serve as attractants for tachinids to localize the habitats occupied by their hosts, and close-range cues can be used to locate the host. Close-range cues include odours associated with the host, such as host secretions, or excretions (particularly "frass"), and visual detection (Stireman et al., 2006; Turling et al., 1995; Hilker et al., 2002; Tscharntke \& Hawkins, 2002; Dindo \& Grenier, 2014). For example, in Exorista larvarum, the most important chemical cue in host localization by females is host-induced plant volatiles, while visual cues, natural maize volatiles and artificially damaged plants were less efficient for host localization (Depalo et al., 2012). For E. larvarum, host motion is also a very important cue for host location, similarly to other tachinids displaying direct oviposition modes, including the congeneric Exorista mella Walker (Stireman, 2002).

As host plant secretions or excretions that could act as attractants for parasitoids, in northern Europe, Lonicera implexa Aiton leaves bearing egg clusters of E. aurinia aurinia have higher concentrations of iridoid glycosides than leaves on plants that bore no eggs. These foliar iridoid concentrations were likely the result of a plant response to egg deposition (Peñuelas et al., 2006); Succisa pratensis Moench plants release a blend of volatile compounds in response to the attack by E. aurinia larvae (Peñuelas et al., 2005). In Europe, Succisa pratensis releases methanol as a defence reaction to larvae of $E$. a. aurinia (Peñuelas et al., 2005); Veronica spicata L., one of the host plants of $M$. cinxia, emits a blend of volatile organic compounds that are involved in the attraction of predators and parasitoids and act as an indirect defence of plants (Pinto-Zevallos et al., 2013). In Finland, Cotesia melitaearum (Wilkinson 1937) (Hymenoptera: Braconidae) and Hyposoter horticola (Gravenhorst 1829) (Hymenoptera: Ichneumonidae) are two specialist parasitoids of $M$. cinxia that forage for different stages (larvae and eggs) and may rely on different herbivore-induced cues to locate the host. Herbivore-induced VOCs that are emitted by V. spicata L. for the presence of $M$. cinxia larvae may be responsible for the attraction of the parasitoid C. melitaearum V. spicata L. infested by M. cinxia larvae in the field (Van Nouhuys \& Hanski, 1999). Therefore, there is evidence that $H$. horticola responds to volatiles emitted from oviposition-induced VOCs (Castelo et al., 2010).

In our study area, the larvae of E. a. provincialis feed on $G$. cruciata, S. columbaria, C. leucantha and L. caprifolium (Pinzari et al., 2017) and the larvae of M. cinxia feed on Plantago sp.

Although the role of volatile compounds in attracting parasitoids has not yet been investigated for our species, according to available literature on this topic, it is likely that the host plants of our studied butterflies emit volatile compounds which may have an attractive role. The discovery of E. furibunda specimens only on E. a. provincialis nests indicated that the butterfly attractants are very successful and perform well even from afar. On the other hand, E. festinans adults were never observed on the larval webs of E. aurinia and therefore we excluded that their choice could be based on some criteria "up close". Unfortunately, the same does not apply to E. furibunda 
and $E$. festinans on the larval webs of $M$. cinxia, since we have never seen any Erycia species on them.

Furthermore, various entomophagous insects are able to recognize the plants free of larvae, the plants that are devoured by caterpillars and the faeces of caterpillars on the basis of the different volatile compound released, as in Spodoptera exigua (Hübner 1808) (Lepidoptera, Noctuidae) (Turlings et al., 2002). As stated before, also during our observations in the wild we recorded several arthropods on plants attacked by caterpillars and almost none on plants without caterpillars. Although the role of chemical cues in host finding requires further research, according to our observations the plants without feeding damage do not attract beneficial insects, except those for dietary reasons on flowers (bees, butterflies, etc.). Only when the eggs of E. aurinia hatch and caterpillars attack the host plants, predators and parasitoids make their appearance: the larval pupal parasitoid Erycia furibunda (Pinzari et al. 2017); hemipterans species like Spilostethus saxatilis (Scopoli 1763) and Palomena prasina (Linnaeus 1761) which feed on faeces (Pinzari, 2016) and the generalist predators of caterpillars Picromerus bidens (Linnaeus 1758) (Konvicka et al., 2005; Pinzari et al., 2019) and Deraeocoris schach (Fabricius 1781) (Pinzari, 2016). The spider Phylloneta sisyphia (Clerck 1757), which preys on all insects that frequent the plants including the caterpillars of E. aurinia and its parasitoids, can be found (Pinzari, 2019).

\section{The impact of dipteran parasitoids on the studied butterflies}

In this study we found a continuous incidence of the parasitoids Erycia furibunda and E. festinans respectively on E. a. provincialis and $M$. cinxia (Table 1). The recorded RPE values seem comparable to the values $(11.1 \%$ and $4.5 \%)$ reported for E. furibunda by Stefanescu et al. (2009) in their 2-year study on the parasitoid complex attacking Euphydryas aurinia and Euphydryas desfontainii (Godart 1819) in Spain. The recorded RPE values have to be considered bearing in mind that they are calculated on the chrysalises, that is on the surviving caterpillars. Erycia furibunda and E. festinans are larval-pupal parasitoids (Shaw et al., 2009), therefore, most maggots are likely to die together with the I-III prediapause caterpillars that did not survive due to summer droughts, winter and spring rigors and, parasitoid and predator attacks, probably more numerous than those known (Pinzari et al., 2016; Pinzari, 2019; Pinzari et al., 2019c). This fact is consistent with the reproductive strategy used both by butterflies and flies to oviposit numerous eggs.

The period of study was too short to have indications of the impact of natural enemies, such as parasitoids, on butterfly population size and further research on parasitism is needed (with a survey on abundance of adults) to draw any conclusions. However, the revealed difference in the rate of parasitism seems to be consistent with the adult population dynamics described in the past by Ford \& Ford (1930) for E. aurinia and by Nieminen et al. (2004) for $M$. cinxia, typically affected by fluctuations, suggesting a possible role of E. furibunda and E. festinans, respectively, as a control agents of population size of E. a. provincialis and M. cinxia in Central Italy.

\section{Conclusions}

Our 5-year observations show that the two parasitoids are specific for the two butterflies: Erycia furibunda parasitizes only Euphydryas aurinia and Erycia festinans parasitizes only Melitaea cinxia.

\section{Acknowledgments}

My sincere thanks in Prof. V. Sbordoni who inspired me to the study of biology and ecology of the Marsh fritillary butterfly, for providing continuous support and advice to my work. The present study was part of the project of the Osservatorio per la Biodiversità del Lazio (OBL), which was coordinated by Prof. Valerio Sbordoni at the Department of Biology, Tor Vergata University of Rome on behalf of the Assessorato Ambiente e Cooperazione tra i Popoli della Regione Lazio, addressed to outline the guidelines to monitor species protected under the Habitat Directive 92/43/CEE (Art. 17, par. 1). Since E. aurinia is a species protected under the Habitats Directive (92/43/EEC), sample collecting was performed under permission of The Ministry of Environment (Prot.0032150 - 23/04/2013 -PNM-II).

We are very grateful to Dr. Pierfilippo Cerretti (University of Rome, La Sapienza) for confirming the identification of Erycia species, to Dr. Hanspeter Tschorsnig (Staatliches Museum für Naturkunde Stuttgart, Germany) for the identification of tachinids, and Dr. Mark R. Shaw (National Museums Scotland, Edinburgh, United Kingdom) for the identification of braconids and icneumonids (Hymenoptera). Special thanks go to Mrs. Samantha Blackman for her assistance in English editing and language review of the final version.

\section{References}

BALLETTO E., BONELLI S., BARBERO F., CASACCI L.P., SBORDONI V., DAPPORTO L., SCALERCIO S., ZILLI A., BATTISTONI A., TEOFILI C., RONDININI C., 2015 - Lista Rossa IUCN delle Farfalle Italiane - Ropaloceri. Comitato Italiano IUCN Ministero dell'Ambiente e della Tutela del Territorio e del Mare, Roma.

BALLETTO E., CASSULO L., BONELLI S., 2014 - Annotated Checklist of the Italian Butterflies and Skippers (Papilionoidea, Hesperiioidea). - Zootaxa,1: 1-114.

BELSHAW R., 1994 Life history characteristics of Tachinidae (Diptera) and their effect on polyphagy. In: HAWKINS B.A., SHEEHAN W., Parasitoid community ecology. - Oxford University Press, New York: 145-162.

CASTELO M.K., VAN NOUHUYS S., CORLEY J., 2010 Olfactory attraction of the larval parasitoid, Hyposoter horticola, to plants infested with eggs of the host butter-fly, Melitaea cinxia. J. Insect Sci. 10: 53, https://doi.org/10.1673/ 031.010 .5301

CERRETTI P., TSCHORSNIG H.P., 2010 - Annotated host catalogue for the Tachinidae (Diptera) of Italy. - Stuttgarter Beiträge zur Naturkunde A, 3: 305-340.

DEPALO L., DINDO M.L., EIZAGUIRRE M., 2012 - Host location and suitability of the armyworm larvae Mhytimna unipuncta for the tachinid parasitoid Exorista larvarum. BioControl 57: 471-479.

DINDO M.L., 2011 - Tachinid parasitoids: are they to be considered as koinobionts? - BioControl 56: 249-255.

DINDO M.L., GRENIER S., 2014 - Production of Dipteran Parasitoids. In: MORALES-RAMOS J., GUADALUPE ROJAS M., SHAPIRO-ILAN D., Mass Production of Beneficial Organisms: Invertebrates and Entomopathogens. Academic Press, London, UK: 101-143.

DINDO M.L., NAKAMURA S., 2018 - Oviposition Strategies of Tachinid Parasitoids: Two Exorista Species as Case Studies. Int. J. Insect Sci. 10: 1-6 
FEENER D.H., BROWN B.V., 1997 - Dipterans as parasitoids. Annu. Rev. Entomol. 42: 73-97.

FORD H.D., FORD E.B., 1930 - Fluctuation in numbers, and its influence on variation, in Melitaea aurinia, Rott. (Lepidoptera). - Ecol. Entomol. 78: 345-352.

FORD T.H., SHAW M.R., 1991 - Host Records of Some West Palaearctic Tachinidae (Diptera). - Entomol. Rec. J. Var. 103: 23-38.

GODFRAY H.C.J., 1994 - Parasitoids: Behavioural and Evolutionary Ecology. - Princeton University Press, Princeton, USA. 488 pp.

HERTING B., 1960 - Biologie der westpalaarktischen raupenfliegen Dipt., Tachinidae. - Monographien zur Angew. - Entomologie 16: 1-188.

HILKER M., KOBS C., VARAMA M., SCHRANK K., 2002 Insect egg deposition induces Pinus sylvestris to attract egg parasitoids. - J. Exp. Biol. 205: 455-61.

KONVICKA M., HULA V., FRIC Z., 2005 - Picromerus bidens (Heteroptera: Pentatomidae) as predator of the Checkerspot Euphydryas aurinia (Lepidoptera: Nymphalidae). - Entomol. Fennica 16: 233-236.

KUUSSAARI M., SACCHERI I., CAMARA M., HANSKI I., 1998 - Allee effect and population dynamics in the Glanville fritillary butterfly. - Oikos 82: 384-392.

KUUSSAARI M., VAN NOUHUYS S., HELLMANN J.J., SINGER M., 2004 - Larval biology of checkerspots. In: EHRLICH P.R., HANSKI I. On the wings of Checkerspots: a model system for population biology. - Oxford University Press, Oxford: 138-158.

MELLINI E., 1991 - Sinossi di biologia dei Ditteri Larvevoridi (Studi sui Ditteri Larvevoridi - L contributo). - Bollettino dell'Istituto di Entomologia "G. Grandi" dell'Università di Bologna 45: 1-38.

MELLINI E., MALAGOLI M., RUGGERI L., 1980 - Substrati artificiali per l'ovideposizione dell'entomoparassita Gonia cinerascens Rond. (Diptera Larvaevoridae) in cattività. Bollettino dell'Istituto di Entomologia "G. Grandi" dell'Università di Bologna 35: 127-156.

NIEMINEN M., SILJANDER M., HANSKI I., 2004 - Structure and dynamics of Melitaea cinxia metapopulations. In: EHRLICH P.R., HANSKI I., On the wings of Checkerspots: a model system for population biology. Oxford University Press, Oxford: 63-90.

PEÑUELAS J., FILELLA I., STEFANESCU C., LLUSIÀ J., 2005 - Caterpillars of Euphydryas aurinia (Lepidoptera: Nymphalidae) feeding on Succisa pratensis leaves induce large foliar emissions of methanol. - New Phytol. 167: 851-857.

PEÑUELAS J., SARDANS J., STEFANESCU C., PARRELLA T., FILELLA I., 2006 - Lonicera implexa leaves bearing naturally laid eggs of the specialist herbivore Euphydryas aurinia have dramatically greater concentrations of iridoid glycosides than other leaves. - J. Chem. Ecol. 32: 1925-1933.

PINTO-ZEVALLOS D.M., HELLEN H., HAKOLA H., VAN NOUHUYS S., HOLOPAINEN J.K., 2013 - Induced defenses of Veronica spicata: Variability in herbivore-induced volatile organic compounds. - Phytochem. Lett. 6: 653-656.

PINZARI M., 2016a - Scythris clavella (Zeller, 1855) in Italy (Lepidoptera, Gelechioidea, Scythrididae). - J. Entomol. Acarol. Res. 48: 301-303.

PINZARI M., 2016b - Deraeocoris schach, a new predator of Euphydryas aurinia and other heteropteran feeding habits on caterpillar web (Heteroptera: Miridae; Lepidoptera: Nymphalidae). - Fragm. Entomol. 48: 77-81.

PINZARI M., 2019 - Phylloneta sisyphia (Araneae: Theridiidae), a predator of larvae of Euphydryas aurinia (Lepidoptera:
Nymphalidae) and its parasitoid Erycia furibunda (Diptera: Tachinidae). - Acta Zool. Bulgar. 71: 195-200.

PINZARI M., CIANFERONI F., FABIANI A., DIOLI P., 2019a Predation by nymphs of Picromerus bidens (Heteroptera: Pentatomidae, Asopinae) on caterpillars of Euphydryas aurinia provincialis (Lepidoptera: Nymphalidae) in Italy. - Redia 102: 89-94.

PINZARI M., PINZARI M., 2019a - Genus Pempeliella Caradja, 1916 and P. bayassensis Leraut, 2001 (Lepidoptera, Pyralidae) in Italy. - ZooKeys 854: 131-144.

PINZARI M., PINZARI M., 2019b - Genus Delplanqueia Leraut, 2001 and D. inscriptella (Duponchel, 1836) (Lepidoptera: Pyralidae) in Italy. - J. Entomol. Acarol. Res. 51: 8168.

PINZARI M., PINZARI M., 2019c - Contribution to the knowledge of Lampedusa lepidopterans. Bifascioides leucomelanella (Rebel, 1917) and Ceutholopha isidis (Zeller, 1867) (Lepidoptera) new for Italy. - J. Entomol. Acarol. Res. 51: 8031.

PINZARI M., PINZARI M., SBORDONI V., 2016 - Egg laying behaviour, host plants and larval survival of Euphydryas aurinia provincialis (Lepidoptera Nymphalidae) in a Mediterranean population (Central Italy). - Boll. Soc. Ent. Ital. 148: 121-140.

PINZARI M., PINZARI M., SBORDONI V., 2017 - Notes on LifeHistory of Erycia furibunda (Diptera: Tachinidae), a parasitoid of Euphydryas aurinia provincialis (Lepidoptera: Nymphalidae). - Redia 100: 81-87.

PINZARI M., PINZARI M., SBORDONI V., 2019b - Make it simply: the mating behaviour of Euphydryas aurinia provincialis (Lepidoptera: Nymphalidae). - Eur. Zool. J. 86: 220-232.

PINZARI M., PINZARI M., ZILLI A., 2010 - Deep lepidopterological exploration of Mt Cagno and surroundings (Central Italy), a restricted mountain Massif and hotspot for butterfly and moth diversity. - Boll. Assoc. Rom. Entomol. 65: 3-383.

PINZARI M., SBORDONI V., 2013 - Species and mate recognition in two sympatric Grayling Butterflies: Hipparchia fagi and $H$. hermione genava (Lepidoptera). - Ethol. Ecol. Evol. 25: 28-51.

PINZARI M., SANTONICO M., PENNAZZA G., MARTINELLI E., CAPUANO R.M., PAOLESSE R., DI RAO M., D'AMICO A., CESARONI D., SBORDONI V., DI NATALE C. 2018a Chemically mediated species recognition in two sympatric Grayling butterflies: Hipparchia fagi and Hipparchia hermione (Lepidoptera: Nymphalidae, Satyrinae). - Plos One 13: e0199997.

PINZARI M., ZERUNIAN Z., PINZARI M., 2018b - Is the alien species Clepsis peritana (Lepidoptera: Tortricidae) settling in Italy? - J. Entomol. Acarol. Res., 50: 1-3.

PORTER K., 1981 - The population dynamics of small colonies of the butterfly Euphydryas aurinia [D. Phil. Thesis]. - University of Oxford, Oxford (UK).

SHAW M.R., STEFANESCU C., VAN NOUHUYS S. 2009 Parasitoids of European butterflies. In: SETTELE J., SHREEVE T., KONVICKA M., VAN DYCK H., Ecology of butterflies in Europe. - Cambridge University Press, Cambridge: 130-156.

STEFANESCU C., PLANAS J., SHAW M.R., 2009 - The parasitoid complex attacking Spanish populations of Euphydryas aurinia and Euphydryas desfontainii (Lepidoptera: Nymphalidae, Melitaeini). - J. Nat. Hist. 43: 553-568.

STIREMAN III J.O., 2002 - Host location and selection cues in a generalist tachinid parasitoid. - Entomol. Exp. Appl. 103: 23-34.

STIREMAN J.O., O'HARA J.E., MONTY WOOD D., 2006 Tachinidae: Evolution, Behavior, and Ecology. - Annu. Rev. Entomol. 51: 525-555. 
TSCHARNTKE T., HAWKINS B.A., 2002 - Multitrophic Level Interactions, Cambridge University Press: $284 \mathrm{pp}$.

TSCHORSNIG H.P., 1996 - Hilltopping Tachinidae from western Europe. - The Tachinid Times, 9: 3-4.

TSCHORSNIG H.P., 2018 - Preliminary host catalogue of Palaearctic Tachinidae (Diptera) http://www.nadsdiptera.org/ Tach/World Tachs/CatPalHosts/Home.html, Accessed on 28 April 2018.

TSCHORSNIG H.P., HERTING B., 1994 - Die Raupenfliegen (Diptera: Tachinidae) Mitteleuropas: Bestimmungstabellen und Angaben zur Verbeitung und Okologie der einzelnen Arten. Stuttg. Beitr. Naturk.(A) 506: 1-170.
TURLINGS T.C.J., GOUINGUENÉ S., DEGEN T., FRITZSCHEHOBALLAH M.E., 2002 - The chemical ecology of plant-caterpillar-parasitoid interactions. In: TSCHARNTKE T., HAWKINS B.A., Multitrophic Level Interactions. - Cambridge University Press: 148-173.

VAN NOUHUYS S., HANSKI I., 1999 - Host diet affects extinctions and colonisations in a parasitoid metapopulation. J. Anim. Ecol. 68: 1248-1258.

VAN NOUHUYS S., HANSKI I., 2004 - Natural Enemies of Checkerspots. In: EHRLICH P.R., HANSKI I., On the wings of Checkerspots: a model system for population biology. - Oxford University Press, Oxford: 161-180. 